\title{
Affirmation, Acceptance and Rejection: Polish contemporary Documentary Film- makers and their Relation to Poland's Documentary Film Tradition
}

Images vol. XV/no. 24

Poznań 2014

ISSN 1731-45Ox

A registry office. A young, unassuming and insecure blonde enters escorted by a well-built man to have the birth of their baby recorded. She signs documents given to her by the official, watching the man, who observes her every movement, out of the corner of her eye. To the question where the child is going to live, he answers without hesitation: "With me". When the official asks about the child's surname, it is his that he provides. "All yours - your surname, your address", comments the lady as she takes the notification. The young woman starts to have misgivings. She returns to the counter and asks about giving the child her surname. After being told that in such a case the father must give his consent, she steps out to talk to him in the corridor, only to return downcast and to ask to have the original entry kept in the documents. This scene is cut by a fragment of a scene from another part of the office. An elderly lady notifies the office of the death of her husband. The official shows her some sympathy. The lady then says that her marriage was far from ideal, that she had loved but also hated him, and as far as she was concerned her husband had ceased to exist many years ago. The ultimate death was only the sealing of the first, moral one.

The scene above is the climax of The Lucky Ones (Szczęściarze, 2009), an award-winning documentary by Tomasz Wolski. One of the awards it received was the Audience Award at the Kraków Film Festival. The emotional charge the scene carries, the human drama it depicts and its compact dramatic structure, make it justifiably the crucial scene of the film, perfectly reflecting the work method used by Wolski to shoot it. As a place for documentary observation, the director chose an institution where people come when their lives take significant turns. Thus, we expect to see happy people and others in despair, those full of hope and others deprived of any illusions.

There are recurrent scenes in The Lucky Ones of couples setting a date for their wedding and of fathers notifying the office of the birth of their children, scenes of marriage ceremonies and anniversary celebrations, and shots of spouses reporting the death of a husband or wife. These strands are interlaced in the film, but soon a pattern according to which they were arranged becomes easily discernible. The first minutes of The Lucky Ones are dominated by shots of young couples and young parents. With time, there are more and more older women and men 


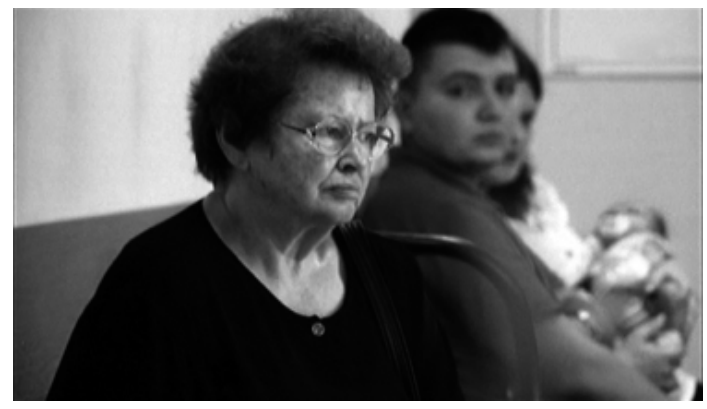

dressed in black, and wedding ceremonies are replaced by the ceremonies of granting medals for many years of married life. The collective portrait builds a model human biography, acquiring a metaphorical dimension. This is not, however, an overstressed pattern. It follows rather from the shifting emphasis and anticipations obtained through the skill of editing. A couple setting a date for their wedding is set alongside, for instance, a happy

The Lucky Ones, dir. T. Wolski, 2009 father reporting the birth of his second daughter. The shot of a pregnant tummy hugged by the white dress of a bride is given the background of a baby's cry.

The next sequence, however, shows a mother with a baby in the corridor - and suddenly the sound we thought was non-diegetic, turns out to have its source within the film's world. Sometimes scenes are arranged in such a way that the fate of older people is a projection, as it were, of the fate of the young. It is not without reason that the climax scene mentioned earlier is cut by a comment of a widow full of sorrow and a sense of failure. At the same time, Wolski describes the relationship between his protagonists in a subtle manner; it is based on a clear domination by one person and a gradual withdrawal by the other. It is from such a relationship that the bitterness of the widow in the scene described earlier could have been borne. The young couple, in turn, arguing about the child, is also one of the possible variants of the widow's past.

Joy and happiness are confronted with sadness or anger within a single scene, or even a single shot or frame. When an official talks to a happy father (it is then that the words chosen for the film title are spoken), a telephone rings. Somebody from a hospital asks about the necessary formalities to be completed upon the occurrence of a stillbirth. During weddings, emotions are sometimes relieved by crying, while sometimes they are shown through a mild smile of resignation when a dead person is mentioned in a conversation. In the scene showing the anniversary celebrations, there is a lot of official routine going on, which at a certain moment reveals the relationship between its protagonists. An elderly woman-official hands out medals to couples as if she were standing on an assembly line uttering the mandatory formula: "In the name of the President of the Republic of Poland I present you with this medal..." A younger official encourages the decorated couples to take to the floor and to tell the younger generations how and on what foundations to build lasting relationships. The hall falls silent. Some smile slightly, othersretain sad faces, still others look around nervously waiting for somebody to speak. We will not hear any answer to these difficult questions in the film. In an interview, the director emphasized:

This is a film about changing, not always successful man-woman relationships. After all, in the beginning we see a happy couple who imagine how happy they are going to be together. But life verifies everything anyway 
and these histories go one way or the other. Sometimes people are happy with each other, sometimes they live together although they shouldn't, sometimes they part.[1]

Although Wolski's film keeps on confronting happiness with human tragedy, its overall tone is rather cheerful, which is characteristic of his other documentaries too. This is so for the hallmark of the director's work is a search for those areas of reality where the

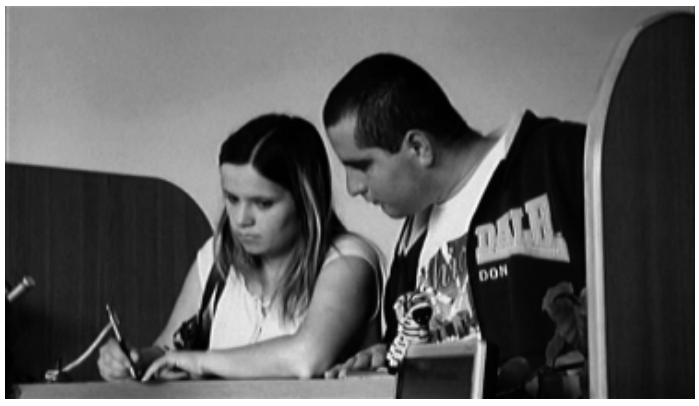
spirit of affirmation prevails, sometimes tinted with a modicum of irony. Hence, in the final scene of the film, he shows a young couple who set The Lucky Ones, a date for their wedding and who look to the future with hope, saying that it is going to improve with each month.

Wolski, a representative of the generation of younger documentary filmmakers, is usually seen as a continuator of the tradition of Polish documentary cinema. Its principal characteristic is the director-driven and artistic nature of documentary work, as well as the domination of a deeply humanistic vision of the world and ethical sensitivity.

It appears that a documentary filmmaker most akin to Wolski is Krzysztof Kieślowski. Associations of The Lucky Ones with such films as The Office (Urzad, 1966) and Refrain (Refren, 1972) immediately come to mind. As a matter of fact, Wolski uses such associations consciously. As a setting, Kieślowski chooses a Social Security Administration (ZUS) office and a state funeral home, while Wolski selects a Registry Office. The choices were motivated by the same idea of showing the protagonists at special moments; beginning with a description in order to build a universal metaphor. It is worth marking, though, significant differences in the nature and intentions of the description. Mikołaj Jazdon stresses:

The Office, Factory, Hospital, Railway Station are not examples of emergency journalism. The documentary filmmaker works on the assumption that in the world of lies, the most precious value and the most effective weapon in the struggle against propaganda falsehood is the most honest approach to the truth about the depicted world. A flaw appears then as part of the world, an element present in it, and, to make matters worse, accepted.[2]

This is how Tomasz Wolski justifies the choice of settings for his documentaries:

These places seem to be quite usual, they often have bad associations in people's minds, but I try to "deal" with them differently. Besides, each time I set out to work on a new film I hope to meet fantastic characters. So far, I have never been disappointed - after each recorded documentary I felt I met two or three unusual people. Not from the limelight. These are common, sometimes ordinary people. Of course, this can hardly be referred

[1] T. Wolski, “Czy są tu miejsca dla mnie?” [Is There a Place for Me Here?]. T. Wolski talks to M. Jazdon and P. Pławuszewski, Images 2012, no. 19. dir. T. Wolski, 2009
[2] M. Jazdon, Dokumenty Kieślowskiego [Kieślowskis Documentaries], Wydawnictwo Poznańskie, Poznań 2002, p. 64 . 


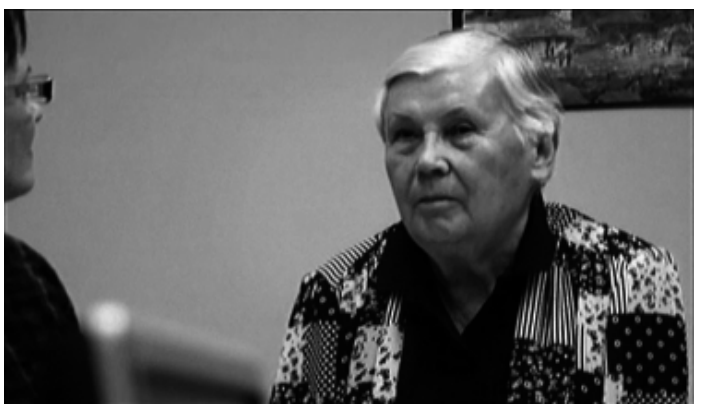

The Lucky Ones, dir. T. Wolski, 2009 to doctors, whose profession as such is unusual, but nonetheless, in documentaries, I have always been attracted by... normality.[3]

Wolski zooms in on the moment when an official cuts off the corner of a plastic identity card. An equivalent shot in Kieślowski's Refrain shows the tearing of a photograph from a paper document. Similar analogies, reminiscences or plain quotations can be found in Wolski's other films - as for instance Doctors (Lekarze, 2011), which evokes associations with Hospital (Szpital, 1977) by Kieślowski. Wolski's attitude to tradition, however, is more complex than would appear at first glance. With direct references, he indeed underscores the continuing tradition of Polish documentary cinema and its significance for a contemporary documentary filmmaker. For Wolski, as for the documentary filmmakers of the 1960s and 1970s, fact-driven cinema remains not only a way of speaking about the present, but it is also an artistic message capable of carrying the universal and metaphorical sense of history. Wolski, however, does not make a gesture of repetition; it is not even a gesture of repetition with a change. His documentary method, although inspired by the works of Kieślowski, departs considerably from the approach to documentary film taken by the author of Railway Station (Dworzec, 1980). In The Lucky Ones, the sources of the metaphorical include words spoken by the characters, or a specific cut and ensuing dramatic tension of the film. In Kieślowski's films, an entirely different method of building a metaphor is used, which makes the meanings it encodes different as well. In both the documentaries by Kieślowski mentioned earlier, the metaphorical sense is concentrated in their final scenes. In The Office, after a series of shots showing people who came to have some official business attended to, there appears a clearly separated epilogue. The camera shows stacks of files accumulated in a ZUS archive while we hear an off-screen voice of an official, who gives a form to for someone to fill in. One of its spaces asksthe person to fill in what he or she has done in his or her entire life!

Throughout the film an exceptionally harsh and critical opinion of the bureaucratic machinery can be sensed. Officials are depicted as basically depersonalized because they depersonalize the people who come to see them. Kieślowski therefore avoids any shots of faces; instead he shows a hand stirring tea in a glass or the sharpening of a pencil, while we hear off-screen the words "please wait" repeated as if they were a mantra. He also focuses on the barriers that separate officials from the people who come to see them, many times using for this purpose the motif of a glass pane. In turn, in the ending of Refrain, we watch, in contrast to the subject of previous scenes in a funeral home, a shot

[3] T. Wolski, op. cit. 
of a ward full of newborn babies. Before the camera moves along the metal hospital beds and we see the number of each baby in the foreground, Kieślowski shows the bands with those numbers being fastened to the babies' wrists. The film is consistent in its building two lines of metaphorical associations: the first of a universal nature is about the inevitability of death, the proximity of birth and death; and the second concerns more directly

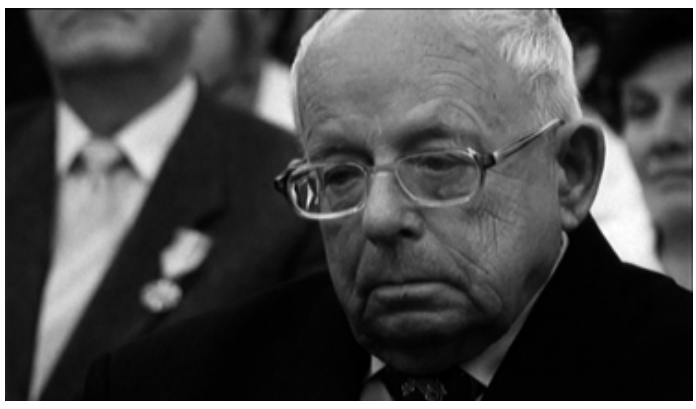
the reality of the People's Poland - where human life was reduced to a number in a system of forced and noxious uniformisation, even in the face of the Supreme.

The camera tracks back and forth, which in an allusion to the title lends the film a characteristic rhythm. It shows employees talking to the relatives of dead people about the type of funeral they would like to give to their beloved, recently departed. The employees are not at all brusque or rude. The depersonalisation of the experience of death follows rather from the fact that burying the dead is strictly regulated by the state. The totalitarian state encroaches even on the intimate areas of life as well as those others that so far have been regulated by ritual only. The camera, tracking from one official to another, uses the colour black as a unifying but also symbolically charged element. From time to time, the camera looks out of the office window, through which we see and hear a bustling street. Thus, both metaphorical lines converge in the epilogue.

In part, the differences in the poetics of The Lucky Ones and Kieślowski’s documentaries follow from their length. To a 40-minute-long film, Wolski can give a plot-like structure. Kieślowski, meanwhile, keeps to the fundamental rules of documentary film, with its tendency for synthetic shots and a clear and strong punch line. Marek Hendrykowski observes:

The art of film synthesis. A lot in a little, the picture of an age in a few-minutes résumé. This is where the magic power of short film lies. A narrative may extend in it over a brief moment or a time interval of any length. Granted, this a characteristic of cinema in general, but in the formula of short film it takes on a special aspect.[4]

In scrutinizing these three films, however banal it may sound, one must not forget about the historical context in which they were shot. This perspective also helps to capture the ambivalent attitude of some contemporary documentary filmmakers to the tradition of fact-driven cinema. Kieślowski shot his early documentaries Factory (Fabryka, 1970), Refrain (Refren, 1972), and Hospital (Szpital, 1977) fully

[4] M. Hendrykowski, Sztuka krótkiego metrażu [The Art of the Short Film], Ars Nova, Poznań 1998, p. 37. 
convinced that there were huge areas of life in People's Poland that had been left undepicted:

There is a reality of people, things and consciousness, of meetings and children's summer camps, the reality of double faith, lies and hope, the reality of party meetings and football matches, of the Peace Cycling Race and political jokes, hospitals and banners.[5]

This reality, in the opinion of the authors of the essay on the undepicted world, was absent from culture. The depiction is the level zero of literature, a point of departure for a reflection transcending what is current.[6] The appeal by the poets sounded, then, incredibly dramatic: "If no efficient culture-making generation, possessing a comprehensive game plan, appears, our world will remain undepicted and will be as mysterious for future generations as Atlantis is to us".[7] The generation which is sometimes labelled a "new shift", shot documentaries in hospitals, schools, or factories in order to show how the socio-political system imposed on Poland worked, that is, if it worked at all. Documentary filmmakers, and not only them, felt they had an important social mission to complete.

Documentaries, remaining an art, served also important social functions. This paradigm of thinking about film art was common until the early 1990s. The change of the political system and cultural transformations made it, however, transform as well. A documentary filmmaker may feel relieved of the duty to satisfy social expectations today. The best evidence that this process is moving on is the emergence of autobiographic documentary in Poland in the late 1990s. For the first time in the history of Polish fact-driven cinema, its authors concentrate on themselves, turn a camera on themselves. Being aware of certain simplifications, it can be claimed that the social commitment of fact-driven cinema, the need to depict uncharted territories and take up absent or "wrongly present" strands, delayed the rise of the autobiographic documentary in Poland so much. However, it is worth noting that another element of the native documentary film tradition - its author-driven character - was conducive to the emergence of so-called auto-documents. This is not to say that socially-committed documentaries of a high artistic value have ceased to be produced in Poland at all. Contemporary Polish documentaries appear to be simply much more diversified, with different strands developing in parallel. Filmmakers employ various poetics without forgetting about the previously strong and peculiar tradition.

An unfounded and grossly unfair charge, it seems in this context, was levied at the film Doctors (director Wolski) by Bartosz Żurawiecki

[5] A. Zagajewski, "Rzeczywistość nie przedstawiona w powojennej literaturze polskiej" [Reality Undepicted in Post-war Polish Literature], in: A. Zagajewski, J. Kornhauser, Świat nie przedstawiony, Wydawnictwo Literackie, Kraków 1974, pp. 43-44.
[6] Ibidem, p. 36.

[7] Ibidem, p. 46. 
in the article Tinkering in the Soul (Gmeranie $w$ duszy). The reviewer wrote in Dwutygodnik:

Wolski's documentary no doubt wishes to allude to the famous 1977 Hospital by Kieślowski in which we saw overworked, poorly paid doctors, discharging their duties without a word of complaint despite the overall material and moral degradation of People's Poland. However (ignoring even the difference in the time of production) Kieślowski's film was critical of the system then in place, while the work of Wolski looks as if it were commissioned by the Main Medical Chamber. It stems from the old-intelligentsia faith in ethos, from the conviction that the ethos continues to "manifest itself" in everyday life. Maybe I could believe in it again had the director shown some conflict in the film, for instance a conflict of values, and had not been scared stiff of touching upon controversial issues related to the situation, conduct or outlook on life shared by Polish doctors. [8]

It is true that Wolski does not focus on the financial standing or organisational problems of health care. He shifts his emphasis with respect to the way Kieślowski laid it years earlier. In The Lucky Ones and Doctors, the universal character of the story moves to the fore the drama of existence, which is sometimes terrifying and sometimes ridiculous. Doctors and, in a way complementary to it, Hospital (Klinika, 2006) are excellent examples of how Wolski's documentary method developed and how he persistently built a director-driven vision of reality, which, however, is quite distant from Kieślowski's. It appears that, despite the homage paid on many occasions to the work of the author of Hospital (Szpital, 1977), the documentary filmmakers are divided over a fundamental issue: the philosophy of cinema. Wolski stresses: "Myself, I try to make films about people whom I like and respect, who for one reason or another are exceptional to me. Negative traits make me withdraw".[9] When Kieślowski, Zygadło and Łoziński made their early documentaries, their films heralded social criticism and stood in clear opposition to the propaganda, the main instrument of which was television. It appears that it is television and reportage that have taken over the investigative function today. No documentary filmmaker is obliged to make social films at present. This certainly is rather a matter of artistic choice and creative temperament.

Wolski's oeuvre is only an example, albeit a significant one. For it is worth taking a broader view on the attitude of contemporary documentary film to the tradition of Polish fact-driven cinema or the "Polish School of Documentary Films".[10]The attitude is complex and very varied. A vast majority of filmmakers stress the importance of the tradition of the 1960 s and 1970s for their own documentary work.

[8] B. Żurawiecki, Gmeranie w duszy, <http://www. dwutygodnik.com/artykul/3829-gmeranie-w-duszy. html> [accessed: October 10th 2013].

[9] T. Wolski, op. cit.

[10] "The Polish School of Documentary Film" is a term much used by journalists and film critics. It can also be encountered in some scholarly publications. However, it has never been precisely defined. See Historia polskiego filmu dokumentalnego [A History of Polish Documentary Film], ed. M. Hendrykowska, Poznań 2015 (forthcoming). 
In a survey carried out by the monthly Znak, the director of Doctors observed:

Of course, this formation is important, but at the same time it is so heavy a burden that a lot of 'correct' and clichéd films are produced in our country. They are rarely critical or bold in the treatment of their subjects and rarely do they open any new spaces of the genre. This applies to me as well. Perhaps, it is so because we worship films made by our older colleagues instead of opposing them and searching for a new way of our own. Although on the one hand the tradition restrains us a lot, on the other hand, our films make their mark at international festivals and many of them win awards - because they have something in common, something that distinguishes them from others - the spirit of the "Polish School of Documentary Film".[11]

The situation of a documentary filmmaker in today's Poland is described thus by Paweł Łoziński, the author of such award-winning films as Birthplace (Miejsce urodzenia, 1992), Sisters (Siostry, 1999), Such a Story (Taka historia, 1999), and Chemo (Chemia, 2009):

If somebody wishes to, he of course may use the term "Polish School of Documentary Films". Why, there must be some common denominator shared by the films from that period. Economy, brevity, conciseness, "feature-film" cut, author's own point of view. These were films made for the cinema, not for television. Today, we are a bit in two minds, we think the "old way", while television sometimes expects something else than we do. We have a great tradition of our own thinking about documentary filmmaking and the world looks for formatted products.[12]

The changes in contemporary documentary cinema are not induced, however, only by the demands of the market. The surrounding reality undergoes continual metamorphoses, and documentary ways of talking about how the world evolves, which makes the overriding power of the "Polish School of Documentary Film" provoke opposition. The best example of a film made in opposition, so to speak, to the main strand of the Polish documentary cinema of the 196os and 1970 is the autobiographic film What a Beautiful Son I Bore (Takiego pięknego syna urodziłam, 1999) by Marcin Koszałka. The diretor, with apparent nonchalance, casts aside the concern for the aesthetic value of the visual picture, so very typical of documentaries by Ślesicki, Karabasz, and later Kieślowski and Łoziński. He reaches for a form which is rather uncommon in the history of Polish non-fiction film, namely home movies. His defiance can also be seen in the manner he took up the issue of family and the mother-son relationship in the documentary, breaking a very strong taboo present in our culture. Thus, he rejected the two pillars, ethical and aesthetic, which underpinned the "Polish School of Documentary Film".

[11] T. Wolski, "Godność kamery" [The Person Behind the Camera]. A survey of documentary filmmakers, Znak 2012, no. 11, <http://www.miesiecznik. znak.com.pl/8322/3/godnosc-kamery> [accessed: November 1st 2013].
[12] P. Łoziński, “Godność kamery”, [The Person Behind the Camera]. A survey of documentary filmmakers, Znak 2012, no. 11, <http://www.miesiecznik. znak.com.pl/8322/3/godnosc-kamery $>$ [accessed: November 1st 2013]. 
Koszalka's several successive films, notably Declaration of Immortality (Deklaracja nieśmiertelności, 2010), revealed an entirely different attitude to the output of the masters of Polish documentary film. Declaration of Immortality is a homage of sorts paid to the work of Wiszniewski - a refined work searching for an answer to some fundamental questions about the purpose of human pursuits and the fear of old age and death. In the film, there are direct references to Wiszniewski, for instance, a slow, majestic tracking of the camera, a manner of framing giving an impression of dealing with a statuesque figure, and editing matching the silent face of the protagonist with his voice heard off-screen. Koszałka shares with Wiszniewski a creative approach to documentary cinema, a frequent use of pre-designed scenes, but also the understanding of a fact-driven film as an "instrument of a social impact".[13]

An equally interesting case of immersion in the tradition of Polish documentary cinema is the output of Wojciech Staron. Like Koszałka and Wolski, Staron goes to extremes to attain the highest quality of the film image possible. It appears that an important point of reference for Siberian Lesson (Syberyjska lekcja, 1998) and Argentinean Lesson (Argetyńska lekcja, 2011) is Kieślowski's cinema, in particular his idea of the "dramaturgy of reality" employed to much success in, to mention but one, First Love (Pierwsza miłość, 1974). It was based on a deep conviction, present also in earlier theoretical reflections, that the filmed reality held dramatic structures, which gave rise to all tales:

\begin{abstract}
Magnificent, rich, ungraspable reality, where nothing repeats itself, where no repeated shots are possible. We need not worry about its development, it will supply us with new, unusual takes every day. Reality - and it is not a paradox - is a solution for documentary film. One needs to believe it fully, to believe in its dramaturgy, in the dramaturgy of reality. [...] The elements of action, surprise, punch line - so important in classic dramaturgy, the elements of suspense, non-denouement, dangling threads - so important in modern dramaturgy - all this is not invented, why, this is imitation of reality (variously viewed). The thing is, you should stop imitating it, stop pretending, you should take it as it is. With its lack of punch lines, with its order and disorder and the same time - this is the most modern and the most true of all structures.[14]
\end{abstract}

Staron records the encounter of his characters (wife and son) with a strange culture, with the Other. He films in Siberia and Argentina. This very moment of being cast into the world governed by laws other than those the characters have been used to, their gradual entering into relationships with their new environment, are the source

[13] The diploma thesis of Wojciech Wiszniewski written in 1975 was entitled Film dokumentalny jako instrument oddziaływania społecznego [Documentary Film as an Instrument for Social Action]. The texts is available from the PWSFTviT Library, Łódź, call number D669.
[14] K. Kieślowski, Film dokumentalny a rzeczywistość [Documentrary Film and the World Outside], a diploma thesis written in the Faculty of Direction, PWSFTviT, Łódź, under the supervision of Jerzy Bossak in 1970. PWSFTviT Library, Łódź, call number D1035, p. 23. Fragments of the thesis were published in Film na Świecie 1992, no. 3-4. 
of the dramatic tension necessary to structure the films. Again, like Wolski and Koszałka, Staron does not make a gesture of repetition. Availing himself of the observation method, he builds on it an author's vision and introduces autobiographical elements. Tradition is a kind of springboard for young documentary filmmakers, but sometimes it can be a burden, too.

The examples of the films of the three filmmakers mentioned above indicate a complex attitudes towards tradition. What they also show is the freedom of artistic choice, which is an undoubted strength of Polish documentaries. A documentary filmmaker does not have to do anything, but he may do a lot today. In the already quoted review, Bartosz Żurawiecki wrote:

Kieślowski stopped making documentaries at a certain moment because he did not want them to influence in any way the fate of the protagonists. Łoziński made a film entitled So It Doesn't Hurt (Żeby nie bolało, 1998) and condemned Koszałka for "killing his mother" in What a Beautiful Son I Bore. It seems that Polish documentary cinema is still shackled by a falsely understood tradition. In the interactive, multimedia world where every day thousands of motion pictures made with all kinds of devices are uploaded, film - especially that known as the documentary - has become an element of the dynamically changing reality. It is no longer possible to retain the position of an objective, distanced observer who does not intend to change the status quo in any way. A question about how far you can go is always good to ask, but a "man with a camera" should be committed to what he is filming or otherwise he will lose credibility. Moreover, the Polish School of Documentary Film was very political in the 1960s and 1970s. It produced irreverent, uncompromising, and highly impudent things. [...] A reform of Polish documentary film should be started, I guess, with making filmmakers aware that there are things on this earth that they clearly haven't dreamed of.[15]

Contemporary Polish documentary films indeed betray a certain unwillingness to take up political issues, which, however, is gradually changing. It is worth remembering that the tradition of engaged documentaries in Poland, to which the author refers, developed under special circumstances created by the political system, and that they had a special trait: a pursuit of universal meanings, to which most of the films by Karabasz, Kieślowski or Łoziński testify.

[15] B. Żurawiecki, op. cit. 